\title{
THE PHOSPHORUS TURNOVER OF CARCINOMA OF THE HUMAN STOMACH AS MEASURED WITH RADIOACTIVE PHOSPHORUS ${ }^{1}$
}

\author{
By JOHN SCHULMAN, JR.,2 MARLENE FALKENHEIM, ${ }^{3}$ AND SEYMOUR J. GRAY \\ (From the Biophysical Laboratory and the Department of Medicine, Harvard Medical School, \\ and the Medical Clinic of the Peter Bent Brigham Hospital, Boston)
}

(Received for publication May 27, 1948)

\section{INTRODUCTION}

The phosphorus turnover of tumors has been widely studied in animals and has been found to be higher than in normal tissues. Several blood dyscrasias have also been investigated extensively (1-3). The high uptake of radiophosphorus by leukemic cells and by red cells in polycythemia vera has been applied to the treatment of these diseases $(4,5)$. Low-Beer and collaborators have observed an increased uptake of radiophosphorus by human breast carcinomas as measured through the skin in vivo (6); but they have derived no information about turnover. Since no studies have been made of the turnover of phosphorus in naturally occurring human cancers, we thought it of interest to investigate the phosphorus turnover of carcinoma of the human stomach, one of the most common of human malignancies. Because phosphorus takes part in so many reactions of the body, it also seemed of interest to determine whether any change in phosphorus metabolism was related to any particular group of compounds. Therefore, the turnover of the acid soluble, lipid, and protein phosphorus fractions was determined independently. The possible existence of quantitative differences in the phosphorus content of normal tissue and of tumor tissue was also investigated.

\section{METHODS}

These studies were made on patients undergoing subtotal gastrectomy, either for malignancy of the stomach or for non-malignant duodenal or gastric disease. The pathological diagnoses and other pertinent data are recorded in Table I. All patients were under the routine care of the surgical service and received blood transfusions and other intravenous medication as indicated.

1 This work was supported in part by the Office of Naval Research.

2 1st Lt., MC, AUȘ. Present Address: Los Alamos Scientific Laboratory of the University of California, Box 1663, Los Alamos, New Mexico.

3 Present Address: Radiation Laboratory, University of California, Berkeley 4, California.
Radioactive phosphorus as $\mathrm{KH}_{2} \mathrm{P} * \mathrm{O}$, was furnished by the Clinton Laboratory at Oak Ridge, Tennessee, and solutions were prepared and standardized by R. F. Cowing of the New England Deaconess Hospital. The original sample was suitably diluted with distilled water and autoclaved. This neutral solution was administered intravenously approximately 36 hours prior to the scheduled time of operation. The chosen dose of 1 microcurie per pound of body weight was based on calculations by Cowing (7) which showed that this would lead to a total body irradiation of not more than $1.5 \mathrm{r}$.

Within one hour after removal of the stomach the mucosa was stripped from the stomach wall and prepared for analysis. In the non-cancerous stomachs mucosa was taken from the greater curvature, lesser curvature and pre-pyloric area; duodenal samples were obtained whenever possible. In the tumor-bearing stomach the position of the lesion was usually such that normal samples of all the areas could not be obtained. Consequently, a sample of normal appearing mucosa as far from the lesion as possible was taken. Histological study later showed that there were no malignant cells in the areas taken as non-cancerous. In the ulcerating tumors the samples were taken from the actively growing edge of the lesion.

The following analyses were performed:

Total phosphorus: $300 \mathrm{mg}$ of tissue were dried in an oven at $110^{\circ} \mathrm{C}$ for two to three hours and then digested with $10 \mathrm{~N} \mathrm{H}_{2} \mathrm{SO}_{4}$ and superoxol.

Acid soluble phosphorus (inorganic phosphate, ester phosphate, adenylic acid, adenosine diphosphate, adenosine triphosphate, creatine phosphate, etc.) : $\mathbf{4 0 0} \mathrm{mg}$ of tissue were minced with scissors and ground with $10 \%$ trichloroacetic acid in a small glass Potter-Elvehjem tissue homogenizer.4 The filtrate was digested with $10 \mathrm{~N}$ $\mathrm{H}_{2} \mathrm{SO}_{4}$ and superoxol.

Lipid phosphorus (lecithins, cephalins, sphingomyelins, etc.) : $500 \mathrm{mg}$ of tissue were finely minced with scissors and ground in the homogenizer with 1:1 ethyl alcoholether mixture. The homogenate was then extracted with two successive portions of alcohol-ether mixture on the steambath for periods of 30 minutes each. The combined extracts were evaporated to dryness and digested with $10 \mathrm{~N} \mathrm{H}_{2} \mathrm{SO}_{\text {, and superoxol. }}$

Protein phosphorus (chiefly nucleoprotein, but includes some phosphoprotein which does not yield nucleic acid upon hydrolysis): This fraction was calculated as the difference between the total phosphorus and the sum of the acid soluble and the lipid fractions.

\footnotetext{
4 Made to specifications by Macalaster Bicknell Company, Cambridge, Mass.
} 
TABLE I

Clinical data on patients

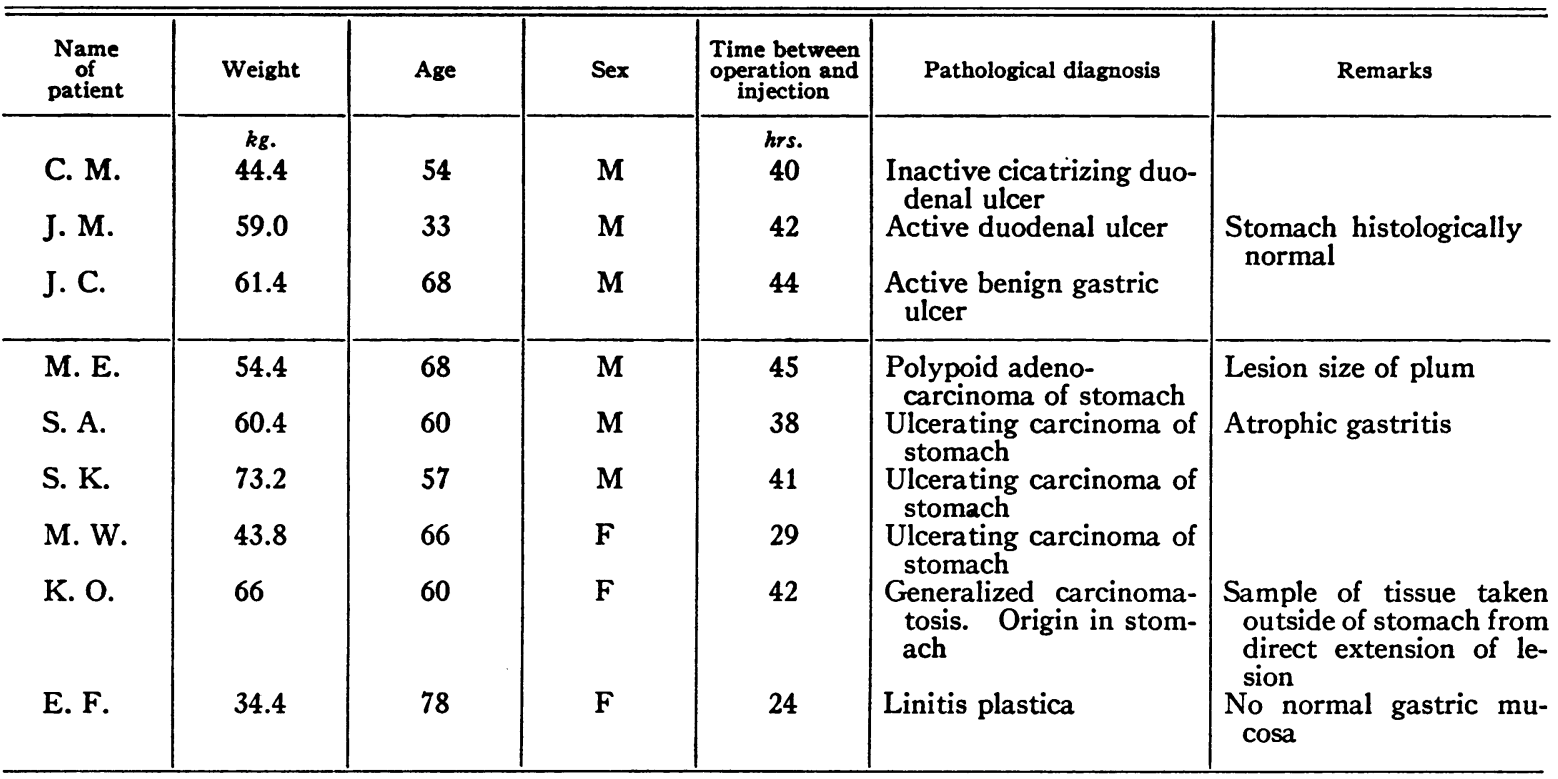

After the digestion, each sample was diiuted to a suitable volume and aliquots were taken of the same sample for counting in solution with a Geiger-Mueller dipping counter (8) and for determination of the phosphorus content by the method of Fiske and SubbaRow (9). The errors of the chemical determination were about $5 \%$, while the counting errors were as high as $10 \%$. The protein phosphorus values, being calculated as differences, have larger errors than the other determinations. Values given in the tables represent averages of duplicate determinations.

Expression of results: Results have been expressed as Biological Concentration Coefficient (10)

$\mathrm{BCC}=\frac{\text { counts per } \min \text { found in sample } / \mathrm{mM}}{\text { counts per min injected/gm body weight }} \times 100$.

This value is a coefficient and has no dimensions.
All data have been analyzed statistically; Fisher's " $t$ " test was used throughout as a criterion of significance (11).

\section{RESULTS}

Phosphorus content: The possible existence of quantitative differences in the phosphorus content of normal gastric mucosa and of cancers was investigated. Table II shows the phosphorus content of the several areas of non-malignant stomachs. Applying Fisher's " $t$ " test to the data in the table, we find that they are statistically homogeneous, i.e., there is no value that varies from the mean of the series by more than could be accounted for by chance. Therefore, the average of these results

TABLE II

Phosphorus content of various areas of non-cancerous stomachs

\begin{tabular}{|c|c|c|c|c|c|c|c|c|c|c|c|c|c|c|c|c|}
\hline \multirow{2}{*}{$\begin{array}{c}\text { Name } \\
\text { of } \\
\text { pa- } \\
\text { tient }\end{array}$} & \multicolumn{4}{|c|}{ Total phosphorus } & \multicolumn{4}{|c|}{ Acid soluble phosphorus } & \multicolumn{4}{|c|}{ Lipid phosphorus } & \multicolumn{4}{|c|}{ Protein phosphorus } \\
\hline & $\begin{array}{c}\text { Greater } \\
\text { curva- } \\
\text { ture }\end{array}$ & $\begin{array}{c}\text { Lesser } \\
\text { curva- } \\
\text { ture }\end{array}$ & Pylorus & $\begin{array}{c}\text { Duo- } \\
\text { denum }\end{array}$ & $\begin{array}{c}\text { Greater } \\
\text { curva- } \\
\text { ture }\end{array}$ & $\begin{array}{c}\text { Lesser } \\
\text { curva- } \\
\text { ture }\end{array}$ & Pylorus & $\begin{array}{c}\text { Duo- } \\
\text { denum }\end{array}$ & $\begin{array}{c}\text { Greater } \\
\text { curva- } \\
\text { ture }\end{array}$ & $\begin{array}{l}\text { Lesser } \\
\text { curva- } \\
\text { ture }\end{array}$ & Pylorus & $\underset{\text { denum }}{\text { Duo- }}$ & $\begin{array}{c}\text { Greater } \\
\text { curva- } \\
\text { ture }\end{array}$ & $\begin{array}{c}\text { Lesser } \\
\text { curva- } \\
\text { ture }\end{array}$ & Pylorus & $\underset{\text { denum }}{\text { Duo- }}$ \\
\hline C. $\mathbf{M}$. & $\begin{array}{c}m M / g m \\
0.0668\end{array}$ & $\begin{array}{c}m M / g m \\
0.0680\end{array}$ & $\begin{array}{c}m M / g m \\
0.0577\end{array}$ & $\begin{array}{c}m M / g m \\
-\end{array}$ & $\begin{array}{c}m M / g m \\
0.0205\end{array}$ & $\begin{array}{c}m M / g m \\
0.0205\end{array}$ & $\begin{array}{c}m M / g m \\
0.0212\end{array}$ & $\begin{array}{c}m M / g m \\
-\end{array}$ & $\begin{array}{c}m M / \mathrm{gm} \\
0.0221\end{array}$ & $\begin{array}{c}m M / g m \\
0.0173\end{array}$ & $\begin{array}{c}m M / \mathrm{gm} \\
0.0123\end{array}$ & $\begin{array}{c}m M / g m \\
-\end{array}$ & $\begin{array}{c}m M / g m \\
0.0213\end{array}$ & $\begin{array}{c}m M / g m \\
0.0297\end{array}$ & $\begin{array}{c}m M / g m \\
0.0245\end{array}$ & $\begin{array}{c}m M / g m \\
-\end{array}$ \\
\hline J. M. & 0.0706 & 0.0461 & 0.0513 & 0.0674 & 0.0205 & 0.0152 & 0.0168 & 0.0158 & 0.0213 & 0.0102 & 0.0121 & 0.0205 & 0.0289 & 0.0206 & 0.0223 & 0.0316 \\
\hline J. C. & 0.0697 & 0.0436 & - & 一 & 0.0237 & 0.0150 & - & - & 0.0155 & 0.0117 & - & - & 0.0300 & 0.0169 & - & - \\
\hline $\begin{array}{l}\text { Aver- } \\
\text { age } \\
\text { S.D. }\end{array}$ & \multicolumn{4}{|c|}{0.0600} & \multicolumn{4}{|c|}{0.0187} & \multicolumn{4}{|c|}{0.0157} & \multicolumn{4}{|c|}{0.0232} \\
\hline
\end{tabular}


TABLE III

Phosphorus content of gastric cancer and of non-cancerous gastric mucosa

\begin{tabular}{|c|c|c|c|c|c|c|c|c|c|}
\hline \multirow{2}{*}{$\begin{array}{c}\text { Name } \\
\text { of } \\
\text { patient }\end{array}$} & \multirow{2}{*}{ Diagnosis } & \multicolumn{2}{|c|}{$\begin{array}{l}\text { Total phosphorus } \\
\mathrm{mM} / \mathrm{gm} \text { tissue }\end{array}$} & \multicolumn{2}{|c|}{$\begin{array}{l}\text { Acid soluble phosphorus } \\
m M / g m \text { tissue }\end{array}$} & \multicolumn{2}{|c|}{$\begin{array}{l}\text { Lipid phosphorus } \\
m M / g m \text { tissue }\end{array}$} & \multicolumn{2}{|c|}{$\begin{array}{l}\text { Protein phosphorus } \\
m M / g m \text { tissue }\end{array}$} \\
\hline & & Cancer & $\begin{array}{l}\text { Non- } \\
\text { cancer }\end{array}$ & Cancer & $\begin{array}{l}\text { Non- } \\
\text { cancer }\end{array}$ & Cancer & $\begin{array}{l}\text { Non- } \\
\text { cancer }\end{array}$ & Cancer & $\begin{array}{l}\text { Non- } \\
\text { cancer }\end{array}$ \\
\hline $\begin{array}{l}\text { C. M. } \\
\text { J. M. } \\
\text { J. C. }\end{array}$ & $\begin{array}{l}\text { Non-cancer } \\
\text { Non-cancer } \\
\text { Non-cancer }\end{array}$ & & $\begin{array}{l}0.0642 \\
0.0590 \\
0.0568\end{array}$ & & $\begin{array}{l}0.0207 \\
0.0170 \\
0.0194\end{array}$ & & $\begin{array}{l}0.0172 \\
0.0160 \\
0.0136\end{array}$ & & $\begin{array}{l}0.025 \\
0.023 \\
0.024\end{array}$ \\
\hline Mean & Non-cancer & & 0.0600 & & 0.0190 & & 0.0157 & & 0.024 \\
\hline $\begin{array}{l}\text { M. E. } \\
\text { S. A. } \\
\text { S. K. } \\
\text { M. W. } \\
\text { K. O. } \\
\text { E. F. }\end{array}$ & $\begin{array}{l}\text { Cancer } \\
\text { Cancer } \\
\text { Cancer } \\
\text { Cancer } \\
\text { Cancer } \\
\text { Cancer }\end{array}$ & $\begin{array}{l}0.0823 \\
0.0771 \\
0.0374 \\
0.0510 \\
0.0558 \\
0.0539\end{array}$ & $\begin{array}{l}0.0329 \\
0.0579 \\
0.0635 \\
0.0435\end{array}$ & $\begin{array}{l}0.0202 \\
0.0234 \\
0.0224 \\
0.0159 \\
0.0161 \\
0.0211\end{array}$ & $\begin{array}{l}0.0120 \\
0.0222 \\
0.0229 \\
0.0172\end{array}$ & $\begin{array}{l}0.0177 \\
0.0171 \\
0.0100 \\
0.0148 \\
0.0114 \\
0.0136\end{array}$ & $\begin{array}{l}0.0100 \\
0.0146 \\
0.0162 \\
0.0121\end{array}$ & $\begin{array}{l}0.045 \\
0.038 \\
0.005 \\
0.020 \\
0.028 \\
0.019\end{array}$ & $\begin{array}{l}0.011 \\
0.020 \\
0.025 \\
0.014\end{array}$ \\
\hline Mean & Cancer & 0.0597 & 0.0494 & 0.020 & 0.019 & 0.013 & 0.013 & 0.025 & 0.017 \\
\hline \multicolumn{2}{|c|}{ Overall mean* } & 0.0597 & 0.0545 & 0.020 & 0.019 & 0.013 & 0.013 & 0.025 & 0.021 \\
\hline \multicolumn{2}{|c|}{ Diff. between means } & \multicolumn{2}{|c|}{$+0.00516=9 \%$} & \multicolumn{2}{|c|}{$+0.001=2 \%$} & \multicolumn{2}{|c|}{ $\pm 0=0 \%$} & \multirow{2}{*}{\multicolumn{2}{|c|}{$\begin{array}{c}+0.0045=2 \% \\
p=0.5\end{array}$}} \\
\hline \multicolumn{2}{|c|}{ Probability } & \multicolumn{2}{|c|}{$p=0.5$} & \multicolumn{2}{|c|}{$p=0.5$} & \multicolumn{2}{|c|}{$p=1$} & & \\
\hline
\end{tabular}

* Mean of all non-cancerous mucosa, regardless of whether stomach bears a cancer.

may be considered to be the mean phosphorus content of the stomach, irrespective of the area of origin.

Table III shows the mean phosphorus content of all the stomachs studied. When non-cancerous stomachs are compared with the non-cancerous portions of cancer-bearing stomachs, there is again no demonstrable difference in the phosphorus content. Therefore, all the non-cancerous mucosae have been grouped as controls and compared with the cancer tissue. The difference in the means of the cancer and the control group is insignificant. Thus, the phosphorus content is the same for all the tissues studied, whether normal or malignant. The same results are found when each of the phosphorus fractions is studied individually.

Biological concentration coefficient: When the Biological Concentration Coefficient after the injection of radioactive phosphorus is studied, however, a difference between cancer and non-cancerous mucosa can be demonstrated. The Biological

TABLE IV

Biological concentration coefficients of various areas of non-cancerous stomachs

\begin{tabular}{|c|c|c|c|c|c|c|c|c|c|c|c|c|c|c|c|c|}
\hline \multirow{2}{*}{$\begin{array}{c}\text { Name } \\
\text { of } \\
\text { patient }\end{array}$} & \multicolumn{4}{|c|}{ Total phosphorus } & \multicolumn{4}{|c|}{ Acid soluble phosphorus } & \multicolumn{4}{|c|}{ Lipid phosphorus } & \multicolumn{4}{|c|}{ Protein phosphorus } \\
\hline & $\begin{array}{c}\text { Greater } \\
\text { curva- } \\
\text { ture }\end{array}$ & $\begin{array}{l}\text { Lesser } \\
\text { curva- } \\
\text { ture }\end{array}$ & $\begin{array}{c}\text { Py- } \\
\text { lorus }\end{array}$ & $\begin{array}{c}\text { Duo- } \\
\text { denum }\end{array}$ & $\begin{array}{c}\text { Greater } \\
\text { curva- } \\
\text { ture }\end{array}$ & $\begin{array}{c}\text { Lesser } \\
\text { curva- } \\
\text { ture }\end{array}$ & $\begin{array}{c}\text { Py- } \\
\text { lorus }\end{array}$ & $\begin{array}{c}\text { Duo- } \\
\text { denum }\end{array}$ & $\begin{array}{c}\text { Greater } \\
\text { curva- } \\
\text { ture }\end{array}$ & $\begin{array}{c}\text { Lesser } \\
\text { curva- } \\
\text { ture }\end{array}$ & $\begin{array}{l}\text { Py- } \\
\text { lorus }\end{array}$ & $\begin{array}{c}\text { Duo- } \\
\text { denum }\end{array}$ & $\begin{array}{c}\text { Greater } \\
\text { curva- } \\
\text { ture }\end{array}$ & $\begin{array}{c}\text { Lesser } \\
\text { curva- } \\
\text { ture }\end{array}$ & $\begin{array}{l}\text { Py- } \\
\text { lorus }\end{array}$ & $\begin{array}{c}\text { Duo- } \\
\text { denum }\end{array}$ \\
\hline C. $\mathbf{M}$. & 2976 & 2821 & 3069 & - & 4216 & 3596 & 3968 & 一 & 2480 & 2511 & 2686 & - & 3007 & 1054 & 2511 & 一 \\
\hline J. M. & 2945 & 3782 & 3379 & 3379 & 5828 & 5673 & 6014 & 5642 & 3162 & 3596 & 3720 & 2759 & 1364 & 2418 & 3844 & 2697 \\
\hline J. C. & 4929 & 5890 & 一 & - & 6541 & 9672 & 一 & 一 & 5642 & 7285 & - & - & 3379 & 1643 & - & 一 \\
\hline $\begin{array}{l}\text { Aver- } \\
\text { age }\end{array}$ & \multicolumn{4}{|c|}{3689} & \multicolumn{4}{|c|}{5673} & \multicolumn{4}{|c|}{3751} & \multicolumn{4}{|c|}{2511} \\
\hline S.D. & \multicolumn{4}{|c|}{104.78} & \multicolumn{4}{|c|}{181.04} & \multicolumn{4}{|c|}{$\quad 164.92$} & \multicolumn{4}{|c|}{954.8} \\
\hline
\end{tabular}


TABLE V

Biological concentration coefficients of gastric cancer and of non-cancerous gastric mucosa

\begin{tabular}{|c|c|c|c|c|c|c|c|c|c|}
\hline \multirow{2}{*}{$\begin{array}{c}\underset{\text { Name }}{\text { of }} \\
\text { patient }\end{array}$} & \multirow{2}{*}{ Diagnosis } & \multicolumn{2}{|c|}{ Total phosphorus } & \multicolumn{2}{|c|}{$\begin{array}{l}\text { Acid soluble phosphorus } \\
\text { BCC }\end{array}$} & \multicolumn{2}{|c|}{ Lipid phosphorus } & \multicolumn{2}{|c|}{$\begin{array}{c}\text { Protein phorphorus } \\
\text { BCC }\end{array}$} \\
\hline & & Cancer & $\begin{array}{l}\text { Non- } \\
\text { cancer }\end{array}$ & Cancer & $\begin{array}{l}\text { Non- } \\
\text { cancer }\end{array}$ & Cancer & $\begin{array}{l}\text { Non- } \\
\text { cancer }\end{array}$ & Cancer & $\begin{array}{l}\text { Non- } \\
\text { cancer }\end{array}$ \\
\hline $\begin{array}{l}\text { C. M. } \\
\text { J. M. } \\
\text { J. C. }\end{array}$ & $\begin{array}{l}\text { Non-cancer } \\
\text { Non-cancer } \\
\text { Non-cancer }\end{array}$ & & $\begin{array}{l}2945 \\
3379 \\
5394\end{array}$ & & $\begin{array}{l}3937 \\
5797 \\
8122\end{array}$ & & $\begin{array}{l}2541 \\
3317 \\
6448\end{array}$ & & $\begin{array}{l}2201 \\
2573 \\
2511\end{array}$ \\
\hline Mean & Non-cancer & & 3906 & & 5952 & & 4092 & & 2418 \\
\hline $\begin{array}{l}\text { M. E. } \\
\text { S. A. } \\
\text { S. K. } \\
\text { M. W. } \\
\text { K. O. } \\
\text { E. F. }\end{array}$ & $\begin{array}{l}\text { Cancer } \\
\text { Cancer } \\
\text { Cancer } \\
\text { Cancer } \\
\text { Cancer } \\
\text { Cancer }\end{array}$ & $\begin{array}{l}4495 \\
6851 \\
5766 \\
5983 \\
7533 \\
4526\end{array}$ & $\begin{array}{l}3689 \\
4588 \\
3875 \\
3999\end{array}$ & $\begin{array}{r}5,921 \\
8,711 \\
7,161 \\
10,323 \\
11,470 \\
6,603\end{array}$ & $\begin{array}{l}5642 \\
7099 \\
8711 \\
8215\end{array}$ & $\begin{array}{l}5239 \\
5332 \\
5425 \\
4743 \\
8432 \\
5456\end{array}$ & $\begin{array}{l}3813 \\
3782 \\
8432 \\
3968\end{array}$ & $\begin{array}{l}3503 \\
6448 \\
3224 \\
3379 \\
4991 \\
1395\end{array}$ & $\begin{array}{r}1643 \\
2511 \\
0 \\
0\end{array}$ \\
\hline Mean & Cancer & 5828 & 4030 & 8,370 & 7409 & 5766 & 3968 & 4030 & 1054 \\
\hline \multicolumn{2}{|c|}{ Overall mean* } & 5828 & 3968 & 8,370 & 6727 & 5766 & 4030 & 4030 & 1798 \\
\hline \multicolumn{2}{|c|}{ Diff. between means } & \multicolumn{2}{|c|}{$1860=47 \%$} & \multicolumn{2}{|c|}{$1643=24 \%$} & \multicolumn{2}{|c|}{$1746=43 \%$} & \multicolumn{2}{|c|}{$2232=124 \%$} \\
\hline \multicolumn{2}{|c|}{ Probability } & \multicolumn{2}{|c|}{$p=0.01$} & \multicolumn{2}{|c|}{$p=0.05$} & \multicolumn{2}{|c|}{$p=0.01$} & \multicolumn{2}{|c|}{$p=0.02$} \\
\hline
\end{tabular}

* Mean of all non-cancerous mucosa, regardless of whether stomach bears a cancer.
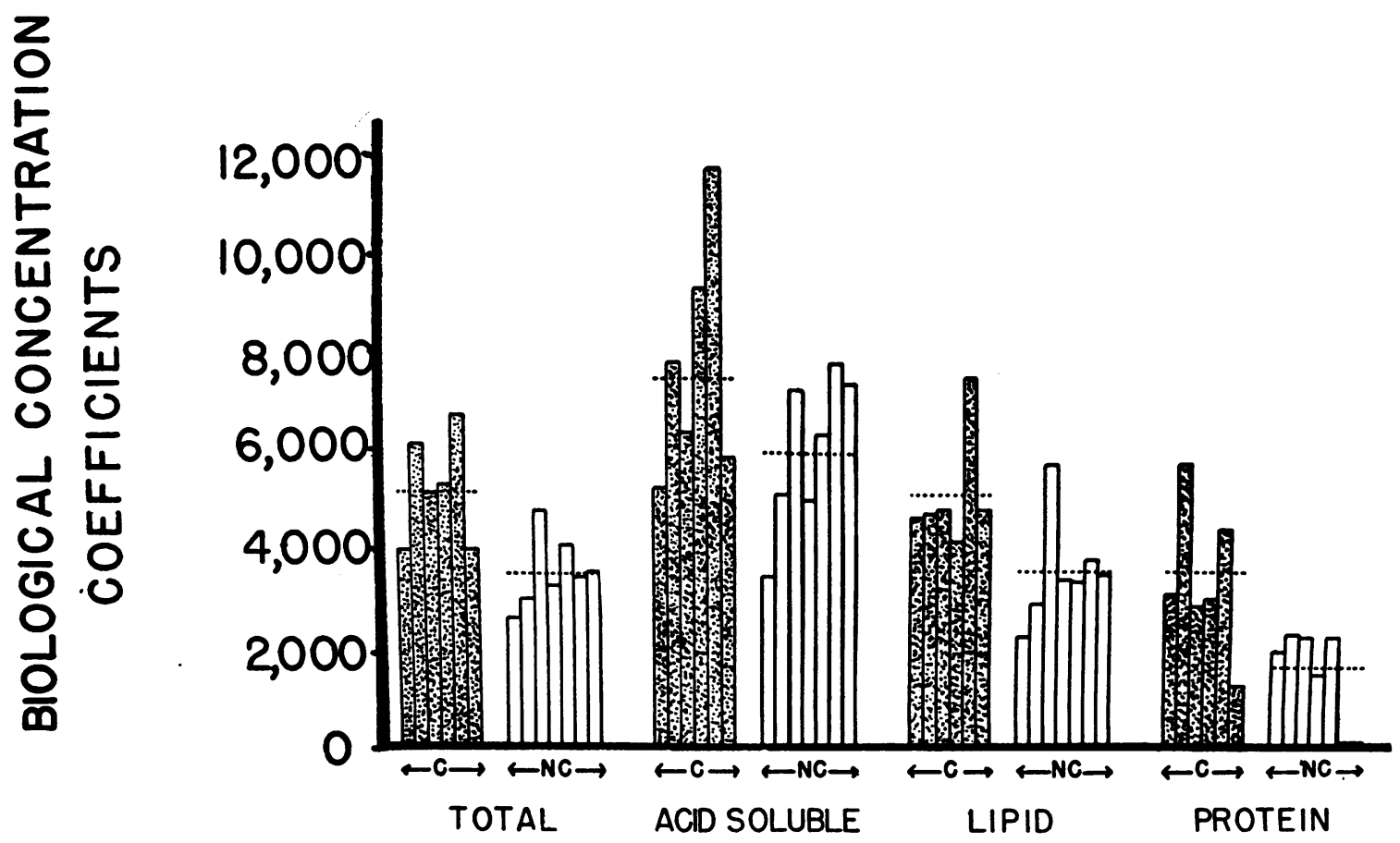

Fig. 1. Biological Concentration Coefficients of Phosphorous Compounds in Non-Cancerous Gastric Mucosa and in Cancer-Bearing Stomachs

The dotted lines represent means. C-cancer; NC-non-cancerous gastric musoca. Each bar represents a patient. 
JOHN SCHULMAN, JR., MARLENE FALKENHEIM, AND SEYMOUR J. GRAY

Concentration Coefficients of the various regions of the normal stomach are the same. The use of an average value is therefore justified (Table IV). Furthermore, there is no significant difference between the non-cancerous mucosa from the cancer-bearing stomach and the mucosa from a stomach that does not bear a cancer (Table V). Therefore, all the non-cancerous samples of mucosa are grouped together regardless of presence or absence of cancer in other parts of the stomach, and their average Biological Concentration Coefficient compared to that of the cancer. This comparison (Figure 1) shows an increase in the Biological Concentration Coefficient of the total phosphorus of $47 \%$ over the normal $(p<0.01)$. The increase in the Biological Concentration Coefficient of the acid-soluble phosphorus is insignificant, but the $43 \%$ increase in the lipid phosphorus and the $124 \%$ increase in the protein phosphorus fractions are both statistically significant $(p<0.01$ and $p=$ 0.02 , respectively).

\section{DISCUSSION}

Since this work was undertaken to study the turnover of phosphorus, i.e., the replacement of phosphorus present by new phosphorus, it was necessary to express results in terms of specific activity-counts per millimole of phosphorus.

Because the radioactivity of a tissue will vary with the administered dose, counts were expressed as fractions of the injected dose. To avoid calculating the decay of the material, the dose was calculated from a standard solution counted on the same day as the samples. It was expressed in terms of body weight in order to compare different patients on the basis of equivalent doses. The factor of 100 is arbitrary. This expression we call Biological Concentration Coefficient.

$\mathrm{BCC}=\frac{\mathrm{Cpm} \text { found in sample } / \mathrm{mM} \mathrm{P}}{\mathrm{Cpm} \text { injected/gm of body weight }} \times 100$.

The use of this expression is discussed at length elsewhere (10).

The expression Biological Concentration Coefficient has two important properties. It has no dimensions and it is not additive. One cannot add the Biological Concentration Coefficient of the acidsoluble fraction to that of the lipid fraction and that of the protein fraction and arrive at the value for the Biological Concentration Coefficient of the total phosphorus.
Phosphorus content: As pointed out previously, no differences were found in the phosphorus content of normal tissue and of the tumor. This is in contrast to the work of Kishi, Fujiwara, and Nakahara (12) who reported that the lipid phosphorus in experimental hepatomas was markedly decreased. Lustig (13) found a low lipid phosphorus content in human lung tumors and a high inorganic and protein phosphorus content. Whether this discrepancy is due to a species difference or a difference in the type or site of tumors studied is impossible to say.

Turnover: It has been shown that the constituents of a tissue are not static. There is a continuous building up and breaking down of tissue. When a tissue remains of constant size, as many atoms of an element must be lost as are being added. The ratio of the atoms added per unit of time to the total atoms of that element present in the tissue is known as the rate of turnover (14). Although this value cannot be determined absolutely except in special cases, relative rates of turnover can be estimated by comparing Biological Concentration Coefficients.

As labeled atoms are incorporated into a tissue their concentration rises rapidly and linearly at first and then slowly levels off to a maximum value. The maximum will be approximately the same for all tissues (15). During the linear portion of the uptake curve the amount of tracer in the tissue will be proportional to the number of new atoms being added, since the number of labeled atoms present is so small that their loss is negligible compared to the total number lost. Therefore, when radioactive phosphorus is administered to a patient and the Biological Concentration Coefficient is determined soon thereafter, the Biological Concentration Coefficient is proportional to the phosphorus turnover during the experimental period.

In practice we cannot assure ideal conditions. The size of the tissue remains constant within the limits of our experimental error. The ratio of tagged to untagged atoms in the plasma is not constant, but our expression has been so devised that the rate of change is probably the same in all subjects. The ideal time to measure the activity of the tissue (if one could obtain countable samples) would be immediately after injection of the isotope. At this time only a few atoms have been incorporated and the Biological Concentration Co- 
efficient will be absolutely proportional to turnover. After this, the uptake curve starts slowly to level off and the Biological Concentration Coefficient will always be less than this value, i.e., it will represent a minimum value. Thus, the differences found are minimum differences, although they approximate the true values.

The rate of phosphorus turnover is at least $45 \%$ higher in gastric cancer than in non-cancerous gastric mucosa. This is in accord with the results found in tumors in experimental animals (1-3).

When the acid-soluble phosphorus compounds were studied the turnover rates in cancer and noncancerous mucosa were found to be essentially the same.

The lipid phosphorus turnover is at least $45 \%$ higher in the tumor than in the non-cancerous tissue. Cell phospholipids are present usually as structural cell components so that this increased turnover probably represents a more rapid cell formation and destruction.

The phosphoproteins-chiefly nucleoproteinsare principally cell building blocks. Therefore, the $124 \%$ increase in the phosphoprotein turnover as compared to normal turnover probably results from enhanced tissue synthesis. Brues, Tracy, and Cohn (16), studying regenerating liver and hepatoma in the rat, found an increased uptake of phosphorus in nucleic acids and found this to be due chiefly to the desoxyribose nucleic acid, the compound present chiefly in the cell nuclei.

There are two possible ways of explaining the increased growth of a tissue. All tissues are continually breaking down old cells and replacing them with new ones. Normally, in the adult tissue the rates of anabolism and catabolism are equal, so the tissue does not change in size. When a tissue is growing, however, this balance is upset. Either formation of new tissue is enhanced or breakdown of old tissue is inhibited. An increased phosphoprotein Biological Concentration Coeffcient represents increased synthesis of phosphoproteins.

Histological evidence of increased mitotic activity would indicate that new cells are being formed. However, new cells might be formed from pre-existing proteins, so that mitotic activity does not necessarily prove that new proteins are being synthesized. Friedberg and collaborators (17) investigated the incorporation of glycine into the tissues of developing embryos and found a high rate of anabolism. Rittenberg, Sproul, and Shemin (18), on the other hand, studying the incorporation of labeled glycine into proteins of regenerating liver, found that it was incorporated at about the same rate as into the proteins of resting livers. From this they concluded that the mechanism of increasing size was the inhibition of the breakdown of tissue. When studying transplanted rat sarcomas, their results were equivocal (19).

Our results tend to agree with those of the former group since the tumor tissues are synthesizing phosphoproteins at more than twice the normal rate. Catabolism must also be increased to some extent, since the increased rate of turnover is much higher than the observed rate of growth. These experiments then, tend to show that the increasing size of a tumor is due to the increased building of cell constituents and an increased breakdown which, however, is not rapid enough to maintain a constant normal size.

Clinically, it has been recognized that on some portions of the stomach, such as the pre-pyloric area and the greater curvature, cancer is common. On the other hand, cancer is less common on the lesser curvature, and is very rare in the duodenum. No satisfactory explanation has been advanced for this. The possibility suggested itself that in the absence of cancer, the regions in which cancer is common had a metabolism more like cancer than did those regions where cancer is rare. The results of studying the few non-cancerous stomachs available tend to show that the rates of phosphorus turnover in all areas of the stomach are the same. Of course, completely normal stomachs are not available as operative specimens.

Another common clinical observation is that cancer of the stomach and atrophic gastritis occur together more frequently than would be expected from their occurrence alone in the general population. This has led to the suggestion that atrophic gastritis might be a precancerous lesion. If this were true, one might expect that the atrophic mucosa would show chemical or metabolic properties intermediate between the cancer and the normal. Cowdry (20) observed this to be the case with many properties of experimental and naturally occurring cancers of the skin. To investigate this possibility the uninvolved mucosa of cancer-bearing stomachs (usually showing atrophic gastritis) was compared with the mucosa of non-cancer-bear- 
ing stomachs. At least in regard to the rate of turnover of phosphorus, no difference could be observed. The evidence tends to show that the malignant type of metabolism is limited to the confines of the tumor itself, and that the rest of the mucosa behaves normally.

\section{SUMMARY}

The phosphorus content and the rate of phosphorus turnover of non-cancerous gastric mucosa and of gastric carcinoma have been measured with the aid of radioactive phosphorus.

1. The rate of turnover of phosphorus by gastric carcinoma is at least $45 \%$ higher than by non-cancerous gastric mucosa.

2. There was at least a $124 \%$ increase in the turnover of protein phosphorus and at least a $45 \%$ increase in turnover of lipid phosphorus; the acidsoluble phosphorus turnover remained unchanged.

3. The increased rate of phosphorus turnover is limited to the cancer itself and is not demonstrable in the surrounding tissue.

4. In the non-cancerous stomach there are no differences in those areas in which cancer is common and in those in which it is rare.

5. There is no difference in the phosphorus content of cancer of the stomach and non-cancerous gastric mucosa.

\section{ACKNOWLEDGMENTS}

The authors wish to thank Dr. A. K. Solomon for designing the counting equipment, and Mrs. J. Harris and Mrs. M. J. McDonald for the determination of the radioactivity of the samples. We are grateful to $\mathrm{Dr}$. DeWitt Stetten, Jr., for his advice and helpful discussions. We also wish to acknowledge the cooperation of Dr. J. Englebert Dunphy, Dr. Francis C. Newton, Dr. James Blodgett and other members of the surgical service for the gastrectomy specimens.

\section{BIBLIOGRAPHY}

1. Jones, A. B., Chaikoff, I. L., and Lawrence, J. H., Phosphorus metabolism of neoplastic tissues as indicated by radioactive phosphorus. Am. J. Cancer, 1940, 40, 243.

2. Burk, D., and Winzler, R. J., Biochemistry of malignant tissue. Ann. Rev. Biochem., 1944, 13, 487.

3. Forssberg, A., and Jacobsson, F., Studies on the Brown-Pearce rabbit carcinoma with the aid of radioactive isotopes. Acta Radiol., 1945, 26, 523.

4. Reinhard, E. H., Moore, C. V., Bierbaum, O. S., and Moore, S., Radioactive phosphorus as a therapeutic agent. A review of the literature and analysis of the results of treatment of 155 patients with various blood dyscrasias, lymphomas and other malignant neoplastic diseases. J. Lab. \& Clin. Med., 1946, 31, 107.

5. Lawrence, J. H., Dobson, R. L., Low-Beer, B. V. A., and Brown, B. R., Chronic myelogenous leukemia. A study of 129 cases in which treatment was with radioactive phosphorus. J. A. M. A., 1948, 136, 672.

6. Low-Beer, B. V. A., Bell, H. G., McCorkle, H. J., and Stone, R. S., Measurement of radioactive phosphorus in breast tumors in situ; a possible diagnostic procedure. Radiology, 1946, 47, 492.

7. Cowing, R. F., Personal communication.

8. Solomon, A. K., and Estes, H. D., Measurement of radioactivity in solution. Rev. Scient. Instruments, 1948, 19, 47.

9. Fiske, C. H., and SubbaRow, Y., The colorimetric determination of phosphorus. J. Biol. Chem., 1925, 66, 375.

10. Schulman, J., Jr., and Falkenheim, M., Presentation of results from radioactive tracer studies. An analysis of expressions found in the literature with suggestions for conventions for future use. $\mathrm{Nu}$ cleonics. In press.

11. Fisher, R. A., Statistical Methods for Research Workers. Oliver and Boyd, Edinburgh, 1946, XV, Ed. 10.

12. Kishi, S., Fujiwara, T., and Nakahara, W. Gann, 1937, 31, 51, 355, 556. Cited by Greenstein, Biochemistry of Cancer. Academic Press Inc., New York, 1947.

13. Lustig, B., Die chemische Zusammensetzung normaler und pathologisch veränderter Organe. I. Mitteilung: Die Zusammensetzung der normalen, carcinomatosen und sarkomatösen Lunge. Biochem. Ztschr., 1936, 284, 367.

14. Stetten, DeWitt, Jr., and Boxer, George, Studies in carbohydrate metabolism. I. The rate of turnover of liver and carcass glycogen, studied with the aid of deuterium. J. Biol. Chem., 1944, 155, 231.

15. Zilversmit, D. B., Entenman, C., and Fishler, M. C., On the calculation of "turnover time" and "turnover rate" from experiments involving the use of labeling agents. J. Gen. Physiol., 1942-43, 26, 325.

16. Brues, A. M., Tracy, M. M., and Cohn, W. E., Nucleic acids of rat liver and hepatoma: their metabolic turnover in relation to growth. J. Biol. Chem., 1944, 155, 619.

17. Friedberg, F., Schulman, M. P., and Greenberg, D. M., The effect of growth on the incorporation of glycine labeled with radioactive carbon into the protein of liver homogenates. J. Biol. Chem., 1948, 173, 437.

18. Rittenberg, D., Sproul, E. E., and Shemin, D., Rate of protein formation in the livers of partially hepatectomized rats. Federation Proc., 1948, 7, 180.

19. Shemin, D., and Rittenberg, D., Some interrelationships in general nitrogen metabolism. J. Biol. Chem., 1944, 153, 401.

20. Cowdry, E. V., Epidermal carcinogenesis. J. A. M. A., 1947, 135, 408. 